\title{
Bone Lesion Identification
}

National Cancer Institute

\section{Source}

National Cancer Institute. Bone Lesion Identification. NCI Thesaurus. Code C132466.

The identification of a localized, pathological, or traumatic structural change, damage, deformity, or discontinuity of the bone. 